MPs' attitudes to welfare: A new consensus?

Hugh Bochel and Andrew Defty Department of Policy Studies University of Lincoln Brayford Pool

Lincoln LN6 7TS

Tel: 01522886098

Email: hbochel@lincoln.ac.uk 


\begin{abstract}
The post-war 'consensus' on welfare was based largely in the perceived agreement of leading politicians of Conservative and Labour parties on the role of the mixed economy and the welfare state. However, from the late 1970s economic and demographic pressures and ideological challenges, particularly from the New Right, led to cuts in spending on welfare, increased private involvement and an emphasis on more individualistic and selectivist approaches to provision. Recently some scholars have begun to discuss the emergence of a 'new liberal consensus' around welfare provision.

Drawing upon interviews with ten per cent of the House of Commons, this article examines the extent to which a new political consensus upon welfare can be identified. In addition to analysing responses to questions upon welfare issues it considers the extent to which MPs themselves believe there to be some degree of consensus in approaches to welfare. It also considers whether any consensus exists merely in the political language used in relation to welfare issues, or whether there is a more substantive convergence.
\end{abstract}




\section{MPs' attitudes to welfare: A new consensus?}

The period from 1945 until the late 1970s has frequently been depicted as being marked by a broad degree of political consensus in a range of policy areas. The broad parameters of this 'consensus' are commonly conceived to encompass: commitment to a mixed economy, full employment, conciliation of the trade unions, state welfare provision, and foreign policy (Kavanagh and Morris, 1994). In the field of welfare this implied a general acceptance of broadly social democratic ideals including: a commitment to the maintenance of large government agencies, most notably the NHS, to provide welfare services to meet a range of social needs free at the point of demand; continued expansion of state welfare provision as the economy grew; and a commitment to maintaining low levels of unemployment through Keynesian economic policies (for example, Lowe, 2005; Thane, 1982; Pierson, 1991). From 1945 to the late 1970s, while support for the welfare state was the subject of periodic intra-party debate, and the boundaries of state provision waxed and waned (mainly the former), the principles of the 'classic' welfare state were upheld by governments of either political hue and enjoyed widespread public support (Lowe, 1999; Timmins, 1995). Although the extent of welfare provision changed as new social problems emerged or priorities shifted, changes, as Peter Taylor-Gooby (1991: 23) observes, were mainly at the margins, 'the core of the state welfare provision went largely unchallenged, either from left or right'.

This broad consensus was put under increasing strain in the 1970s as stagnating economic growth led to rising unemployment, and demographic pressures created by an ageing population led to new and expansive patterns of demand for welfare provision. The Conservative government elected in 1979, influenced by New Right thinking, was committed to reducing the role of the state, promoting the private sector, and introducing free-market principles in the state sector. The Prime Minister, Margaret Thatcher, rejected the politics of consensus in favour of conviction, openly dismissing consensus as 'the process of abandoning all beliefs, principles, values and policies' (Seldon, 1994: 502). The neo-liberal policies of the Thatcher government, led many observers to proclaim the end of the post-war consensus. In 1990, Dennis Kavanagh, the most notable and consistent obituarist for consensus politics, described how Thatcher had either wholly or in part dismantled all the main 'planks' of the post-war consensus. At the same time, he observed, the emergence of the New Right was matched by a 'new left' as the Labour party shifted to the left in response to Thatcherite policies, and a 'new centre' as the newly created SDP sought to occupy the vacant centre ground (Kavanagh, 1990).

The decline of consensus politics under Margaret Thatcher coupled with the opening of archival material related to post-war policymaking, led some to question whether a post-war consensus had ever existed (Pimlott, 1988; Jones and Kandiah, 1996). Nevertheless, consensus has remained an enduring and appealing concept (Addison, 1993; Hickson, 2004). Reviewing the consensus debate in 1994, following the removal of Thatcher, and shortly after the election of Tony Blair to the Labour leadership, Anthony Seldon (1994: 512) identified a new degree of "policy convergence' between the Labour and Conservative front-benches, which he suggested had brought them 'closer on many issues than at any point since the 1970s'. Significantly, Seldon attributed much of this convergence to changes in party leadership. John Major, he observed, embraced a form of Conservatism much closer 
to the One-Nation Conservatism of Butler, Macmillan and Heath than the neoliberalism of Thatcher, while Kinnock, Smith and Blair had each sought to shift the Labour party towards a more centrist position. Seldon, however, remained sceptical about the degree to which the broad areas of agreement between the leadership of the two main parties reflected the views of the bulk of the parliamentary parties. Consequently, while expressing confidence that consensus would continue to be a dominant feature of British politics in the twenty-first century, Seldon stopped short of proclaiming the emergence of a new consensus (Seldon, 1994).

Seldon's caution was born at least in part out of uncertainty as to whether a future Labour government might continue on a centrist course or feel constrained to return to the radicalism of the early 1980s. It is perhaps not surprising then that since New Labour's election in 1997, debate about the emergence of a new consensus has intensified. While the New Labour government elected in 1997 was committed to increased welfare spending there was to be no return to a notional Golden Age of universal welfare provision. Although the pressures of mass unemployment have declined, the demands of pensions and healthcare for an ageing population continue to place considerable strain on the welfare state. These continued demographic pressures, coupled with pressures from the global economy to drive down taxes and regulation, have led to a fundamental shift in Labour party thinking regarding the principle of universal welfare provision. In office New Labour followed many of the policies of the previous Conservative government, including spending restraint, the importation of market principles into the state sector, and emphases on selectivity, individual responsibility and the role of work incentives in relation to benefits (Taylor-Gooby, 2001).

The policies of the New Labour government, particularly in the field of welfare, have led some to suggest that since 1997 policy convergence has transformed into a new consensus between the main parties. Michael Williams (2000) a former Whitehall civil servant, proclaimed the emergence of a new consensus about the role of the state in the 1990s. Nowhere was the new consensus better captured, Williams argued, than in approaches to welfare, where consensus was driven by the need for national competitiveness in a global economy. This was to be achieved in part by fundamental reform of the welfare state aimed at containing public spending; shifting the balance towards services used by most of the electorate; controlling demands on welfare by encouraging claimants to enter the labour market; and modernising public services to raise productivity (Williams, 2000). Focusing in detail on welfare, Peter Taylor-Gooby (2001) has made a similarly convincing case for a new 'liberal' consensus on welfare. Like Williams, Taylor-Gooby explains welfare reform in the UK as a response to labour-market change, demography and globalisation, but also emphasises the electoral imperatives of Britain's two-party system in which parties 'tend to diverge while seeking an electorally viable solutions to problems, but converge on the "middle ground" when a solution that attracts support is found'. That solution, Taylor-Gooby suggests, involves widespread agreement on the retrenchment of spending, the promotion of privatisation in key areas, notably pensions, the targeting of benefits through means testing and other restrictions, and the importance of labour market activation through incentives, training and what is effectively workfare (Taylor-Gooby, 2001: 169). However, while Taylor-Gooby and others have identified a broad degree of policy convergence, Lowe has highlighted continued tensions within the main parties over the movement towards consensus. In particular, 
Lowe highlights a sustained debate within the Conservative Party over the extent to which the welfare state should be dismantled, while also suggesting that the Labour party has been split by a more fractious debate over the extent to which the role of the market should be enhanced in a range of welfare policy areas. Such tensions, Lowe suggests, are not sufficient to invalidate the concept of consensus, but arise from the fact that the two parties have converged from very different ideological positions (Lowe, 2005: 433). These tensions are nevertheless significant and suggest that the movement towards consensus is as much a source of debate within the main parties as between them.

This article examines the extent to which a new political consensus upon welfare can be identified within the House of Commons, using data derived from a series of face-to-face interviews with MPs, carried out between October 2004 and August 2005. The article seeks to analyse MPs' responses to questions about the role of the state in welfare, and also considers the extent to which MPs themselves believe there to be some degree of consensus in approaches to welfare. It examines whether this consensus exists merely in the political language used in relation to welfare issues, or whether there is a more substantive convergence. It focuses on the level of intra-party debate on welfare provision, the future of the welfare state and the welfare policies of the New Labour government since 1997.

This research builds upon work undertaken by Bochel and Taylor-Gooby which surveyed MPs' attitudes to welfare in the late 1980s, at a similar stage in the life of the Thatcher government (Taylor-Gooby and Bochel, 1988; Bochel, 1992). Such detailed research on MPs' attitudes and opinions is notoriously difficult to conduct. Any attempt to construct a representative sample of Parliamentary opinion, is largely dependent upon the willingness of MPs to agree to lengthy face to face interviews (Lilleker, 2003). Nevertheless, this research is based upon a sample of Parliamentary opinion which is broadly representative of the House of Commons as a whole, according to a number of criteria. Sixty-eight MPs were interviewed, a sample comprising ten per cent of the House of Commons balanced for party representation, (32 Labour; 21 Conservative; 10 Liberal Democrat; 2 SNP; 2 Plaid Cymru, 1 Independent). Those interviewed reflected a broad range of Parliamentary experience, including MPs elected to Parliament between 1970 and 2005, and comprised current and former Ministers, select committee members and chairs, experienced backbenchers, and MPs newly elected to Parliament in 2005. While the small numbers involved make cohort analysis difficult, the sample is broadly in line with the composition of the House of Commons, not only in party terms, but also, for example, with 51 per cent of participants elected since the 1997 general election, compared with 61 per cent of the Commons as a whole, and 24 per cent of the sample being women, compared with a figure of 20 per cent of the current House.

The survey took the form of semi-structured interviews, with open-ended questions designed to allow MPs to respond in their own terms to broad questions relating to the role of government in welfare, and more structured questions on specific issues, for example paying for welfare, which allowed for closer comparability of responses. In an effort to militate against MPs merely reciting the party line, the interviews were conducted on a confidential basis, and MPs were encouraged to articulate their personal attitudes and beliefs. Whilst it is impossible to determine the degree to which individual MPs were speaking with absolute candour, 
the success of this approach may in part be revealed by the number of MPs from all parties who were prepared to express opinions at variance with party policy. However, it should also be recognised that MPs within the same party tend to share the same beliefs and values, and more often than not will support the general party line, not because they feel they have to, but because it coincides with their personal beliefs (Cowley, 2005).

\section{What do we mean by consensus?}

An examination of consensus politics in Britain not only involves consideration of the content of that consensus, but also raises questions about the nature of consensus itself. What is meant by consensus? To whom does it apply, and how does one identify it?

The definition of consensus in many respects defines individual positions in the consensus debate. Ben Pimlott, perhaps the most cogent critic of the idea of a post-war consensus, adopted a particularly broad and value-laden definition for which he not surprisingly found few examples in British post-war politics. Consensus, Pimlott argued, is a powerful and emotive term, which means more than mere agreement. 'Consensus,' he asserted, 'is said to exist not when people merely agree, but when they are happy agreeing, are not constrained to agree, and leave few of their number outside the broad parameters of their agreement' (Pimlott, 1988: 130). Moreover, Pimlott suggested that consensus carries with it a value element. It is a positive thing, to be sought after and cherished: "people seek to "embrace", "capture" and "influence" the consensus and are proud to claim possession of it' (1988: 130). After positing such a harmonious definition of political consensus it is hardly surprising that he concluded that the idea of the British post-war consensus is little more than a myth.

In contrast, other observers of post-war politics have employed a more limited definition of consensus, which allows for broad areas of agreement within an adversarial political system. In influential work published in the 1960s, Samuel Beer (1965) was one of the first to identify a broad 'policy convergence' between the Labour and Conservative parties, whilst conceding the existence of marked differences between the main parties in the values which underpinned those policies (Seldon, 1994). This more limited definition of consensus as policy convergence or what David Marquand terms, 'the philosophy of overlap', has been widely embraced (Marquand, 1988). The principal value of this interpretation is that it allows for a substantial measure of party political debate. Kavanagh and Morris, for example, take issue with Pimlott's use of consensus, 'as a synonym for cross-party agreement', asserting that it is better understood as agreement on a broad framework, within which party disagreement would take place: 'A set of parameters which bounded a set of policy options regarded... as administratively practicable, economically affordable and politically acceptable' (Kavanagh and Morris, 1994: 13). These parameters, they argue, merely served to contain the debate, but within them, disagreements were as fiercely contested as ever. Similarly, with regard to welfare, Thane recognised the existence of a broad consensus, but suggested that the post-war Labour government 'used its majority to push the consensus further towards its limits than might have been expected of a Conservative government' (1982: 267). 
This balancing of consensus and conflict is also integral to debate over the locus or extent of political consensus in Britain. Pimlott's suggestion that any consensus should be broadly inclusive has been widely contested by those who have sought to explain debate both within and between parties. Anthony Seldon suggests three distinct groups for the location of political consensus: party supporters; Whitehall officials; and party elites when in office. Popular consensus among party supporters, Seldon suggests is the most easily contested. There is, he argues little evidence for consensus between grassroots Labour and Conservative supporters; rather the further one moves from the party leadership the greater the degree of conflict between the parties. Seldon does however concede that for much of the postwar period there was considerable popular support for state welfare provision, and Rodney Lowe in particular has strongly argued that public demands for social security and full employment were widespread and identifiable features of post-war Britain (Seldon, 1994; 505; Lowe, 2005). There is greater support for the idea of consensus among Whitehall officials. Public choice theory and the burgeoning literature on the civil service has long suggested that the continuity provided by the civil service is at the heart of the post-war consensus. Detailed historical research by writers such as Addison (1975) has provided strong evidence for 'a Whitehall consensus', while Marxist critiques have suggested that consensus was manufactured by senior civil servants as a means of incorporating the Labour movement into the hegemonic values of the state (for example, Miliband, 1983). However, perhaps the most enduring interpretation is the idea of consensus among party elites. This interpretation, stressed by Kavanagh and Morris, suggests that when in office party leaderships naturally gravitate towards the political centre ground and embrace consensual policies designed to retain parliamentary and electoral support. This view also allows for substantial differences between the anti-consensual statements of parties when out of office and policies pursued when elected, and differences of opinion between party leaderships and their backbenchers (Kavanagh and Morris, 1994).

\section{MPs' attitudes to welfare: the role of the state in welfare}

In order to determine the degree of political consensus on welfare, MPs were asked a series of questions designed to reveal their general attitudes towards the role of the state in welfare provision, what might loosely be called their philosophy of welfare, and more structured questions on specific aspects of welfare policy. Their replies were compared with data from Taylor-Gooby and Bochel's survey of 1986-7 in an effort to determine whether any shift in parliamentary political opinion had occurred over the past two decades, and whether that shift represented a movement towards a new consensus on welfare.

While Taylor-Gooby and Bochel were not able to compare their findings with comparable research on MPs' attitudes to welfare at the time of the perceived postwar consensus in the 1950s and 1960s, their research supported the widely held view that there had been a fundamental breakdown in the political consensus on approaches to welfare in the 1980s. On the broad philosophical question regarding the role of the state in welfare, Taylor-Gooby and Bochel found an absence of consensus, and identified a strong division on party lines (Table 1). Conservatives tended to favour a minimalist state that would concentrate its activities on meeting basic needs targeted at a small proportion of the population frequently described as the 'deserving' poor. The most popular description of the role of the state, used unprompted by three- 
quarters of Conservative MPs interviewed by Taylor-Gooby and Bochel, was that of a 'safety-net'. In contrast, Labour MPs were much more inclined to see the ideal role of the state as providing universal services of a high standard, and a substantial minority took the argument beyond universal provision and argued that the state should pursue policies designed to provide equality through redistribution. The SDP/Liberal group comprised only a small part of Taylor-Gooby and Bochel's sample; they tended to favour a high national minimum level of provision, but this was tempered by a concern for the preservation of community and was not necessarily seen as being universal in nature (Bochel, 1992).

TABLE 1. MPs' views on the role of the state in welfare, 1986-7, (Bochel, 1992) (percentage of responses by party).

\begin{tabular}{lccc}
\hline & Labour & Conservative & Liberal/SDP \\
\hline $\begin{array}{l}\text { Safety-net/to meet genuine need only } \\
\text { To support the extension of private }\end{array}$ & 0 & 70 & 0 \\
$\begin{array}{l}\text { welfare } \\
\text { To ensure a high national minimum }\end{array}$ & 0 & 14 & 0 \\
$\begin{array}{l}\text { To an agreed range of services } \\
\text { To meet need }\end{array}$ & 56 & 9 & 75 \\
$\begin{array}{l}\text { To redistribute/advance equality } \\
\text { It depends what the country can }\end{array}$ & 12 & 0 & 0 \\
afford & 29 & 0 & 0 \\
\hline Number & 3 & 2 & 25 \\
\hline
\end{tabular}

When asked the same question in the current survey, although MPs continue to be divided broadly on party lines, there has been a marked movement towards the centre on the part of the three main parties (Table 2). In broad terms Conservative MPs continue to support a more minimalist perception of the role of the state, with considerable support for private provision. Similarly, Labour and Liberal Democrat MPs continue to favour a more collectivist approach to welfare. However, a large proportion of Labour MPs (47 per cent) now suggested a new role for the state in welfare; these MPs supported the idea of a broad state safety-net, but augmented this with the idea that once individuals were caught in the safety-net it was the state's responsibility to propel them quickly back into work. They described the role of the state as, 'more pro-active', 'as an enabler', or 'a mechanism to lift people out of poverty'. While this view was based partly on a belief that for a host of reasons the well-being of individuals is improved through employment, it was primarily a question of cost. As one Labour MP observed, 'the notion of the passive recipient of benefit is no longer valid, apart from anything else large numbers of people on benefit place too much pressure on the economy'. This idea of the welfare state as an enabling mechanism, which featured so prominently in the current survey, did not feature at all in MPs' responses to Taylor-Gooby and Bochel's survey. Support for this more active and selective approach to welfare has, not surprisingly, grown at the expense of support for a high level of universal provision, although support among Labour MPs for redistribution remains relatively high. A similar shift in attitudes may be discerned among Liberal Democrat MPs. Although Taylor-Gooby and Bochel did not speak to many Liberal/SDP MPs in 1986-7, their results indicated strong support for a high national minimum level of welfare provision. In the present survey Liberal Democrat support for universal provision remains high, but a significant proportion of Liberal Democrat MPs have now embraced the idea of the welfare state as an enabling mechanism. 
It is not only those on the left who have changed their views, Conservative MPs have also moved towards the centre. A significantly smaller proportion of Conservative MPs (33 per cent), now believe the government should provide only a safety net for those in the most need, compared with the position in the 1980 s (70 per cent). There has also been a movement away from support for the extension of private provision in favour of a role for the state in working with a number of other providers including charities as a means of addressing welfare challenges such as child and pensioner poverty. Thus, while there is still strong support for a minimalist approach to state provision, a significant minority of Conservative MPs now support a more active role for the state in improving people's lives. This group of MPs, which includes former Ministers from both the Thatcher and Major governments and current Conservative front-benchers, spoke about the role of government in building communities and improving life-chances, in some respects coming close to Labour MPs' views of the state's enabling role. Several went out of their way to dissociate themselves from Thatcherite philosophies, explicitly declaring that 'there is such a thing as society' and that 'people are social animals, not atomised individuals'. A number stressed the importance of combating poverty, particularly among children and pensioners, but were nevertheless keen to stress that the welfare state should not merely hand-out money but should encourage people to help themselves. This emphasis on what more than one Conservative MP termed 'tough love', in which welfare provision is necessary but 'handing out pounds is not enough', has brought the views of Conservative and Labour MPs increasingly into alignment.

TABLE 2. MPs' views on the role of the state in welfare, 2004-5 (percentage of responses by party).

\begin{tabular}{|c|c|c|c|c|c|}
\hline & Labour & Conservative & $\begin{array}{c}\text { Liberal } \\
\text { Democrat }\end{array}$ & $\begin{array}{c}\text { SNP/Plaid/ } \\
\text { Independent }\end{array}$ & $\begin{array}{c}\text { Total } \\
\%\end{array}$ \\
\hline $\begin{array}{l}\text { Safety-net only for those in the most } \\
\text { need }\end{array}$ & 0 & 33 & 0 & 0 & 10 \\
\hline $\begin{array}{l}\text { To support the extension of private } \\
\text { provision }\end{array}$ & 0 & 24 & 0 & 0 & 7 \\
\hline $\begin{array}{l}\text { Beyond a safety-net to work with } \\
\text { individuals and the private sector to } \\
\text { improve lives in a range of sectors }\end{array}$ & 0 & 43 & 0 & 25 & 15 \\
\hline $\begin{array}{l}\text { Beyond a safety net to provide a } \\
\text { mechanism to enable others to lift } \\
\text { themselves out of poverty/into work. }\end{array}$ & 47 & 0 & 40 & 0 & 28 \\
\hline $\begin{array}{l}\text { Provide a national floor above the } \\
\text { minimum level, for a range of } \\
\text { services. }\end{array}$ & 31 & 0 & 50 & 50 & 26 \\
\hline $\begin{array}{l}\text { Redistribution of wealth - provide } \\
\text { social justice. }\end{array}$ & 22 & 0 & 10 & 25 & 13 \\
\hline Number & 32 & 21 & 10 & 5 & 68 \\
\hline
\end{tabular}

This apparent convergence amongst MPs on the role of the state in welfare appears even more pronounced in the analysis of their attitudes towards the nature and extent of state involvement, and in particular the role of the state and the private sector in the delivery of services. In Taylor-Gooby and Bochel's survey there was a marked division between Conservative MPs, who believed that the state should support the extension of the private sector in welfare provision, and Labour MPs who overwhelming supported a high level of state provision. Indeed, Bochel reported that no Labour MPs referred to supporting the private sector as part of the state's role (Bochel, 1992: 54). The current survey indicates a highly significant shift in Labour MPs' attitudes towards the role of the private sector in welfare provision. When 
discussing who should be responsible for provision (Table 3), half of Labour MPs believed that services should be provided mainly by the state, and half believed that there should be a range of providers including the state, private and charitable sector. While Labour MPs continue to believe that the state should be the principal financer of welfare services there is much less concern about who delivers those services. As one Labour MP stated, 'the state will take less of a role in providing but maintain its role as the funder and a guarantor of quality'. This represents a marked shift in Labour MPs' attitudes since the 1980s, and suggests a potentially substantial measure of support for the Labour leadership in seeking to expand the role of the private sector in welfare provision.

TABLE 3. Who should be responsible for providing welfare services? (percentage of responses by party).

\begin{tabular}{|c|c|c|c|c|c|}
\hline & Labour & Conservative & $\begin{array}{c}\text { Liberal } \\
\text { Democrat }\end{array}$ & $\begin{array}{c}\text { SNP/Plaid/ } \\
\text { Independent }\end{array}$ & $\begin{array}{c}\text { Total } \\
\%\end{array}$ \\
\hline Mainly the state & 50 & 0 & 56 & 80 & 37 \\
\hline $\begin{array}{l}\text { A range of providers } \\
\text { including state, private and } \\
\text { charitable sectors }\end{array}$ & 8 & 35 & 33 & 0 & 20 \\
\hline $\begin{array}{l}\text { The public and private } \\
\text { sector in partnership }\end{array}$ & 42 & 30 & 11 & 20 & 32 \\
\hline Mainly the private sector & 0 & 35 & 0 & 0 & 12 \\
\hline Number & 26 & 20 & 9 & 5 & 60 \\
\hline
\end{tabular}

This shift contributes to a considerable degree of overlap between all the main parties in attitudes towards the provision of services. While there was no cross party support for welfare services being mainly provided by the state, a view which no Conservatives supported, or for the view that provision should be mainly the responsibility of the private sector, a view only supported by Conservative MPs, the idea that there should be a range of providers, including the state, private and charitable sectors, received substantial support from all the main parties. This commitment to diversity in the range of provision, with the emphasis on "what matters is what works', rather than who provides services and benefits has been central to Labour policy on welfare since 1997, and arguably lies at the heart of any new consensus on welfare. Although interestingly, a larger proportion of Labour than Conservative MPs referred to the public and private sector working in partnership, while a much larger proportion of Conservative than Labour MPs referred to the charitable sector as a provider of services.

\section{MPs' attitudes to welfare: paying for welfare}

Commitment to diversity in the delivery of welfare is often presented, alongside widespread agreement on retrenchment in spending, as part of a new consensus on welfare (Taylor-Gooby, 2001). However, while there is some clear evidence of consensus on delivery, any consensus on the financing of welfare, at least amongst backbench MPs, is somewhat more ambiguous. While there is considerable overlap in attitudes towards who should provide services, there remain marked divisions between Conservative and Labour MPs regarding the role of the state in the financing of such services (Table 4). Whatever their views on the delivery of services, Labour 
and Liberal Democrat MPs continue to believe that welfare services should be financed by the state through general taxation and national insurance. Conservative MPs believe that individuals should bear some of the burden of the cost, and a significant minority of Conservative MPs (25 per cent) felt that beyond a safety-net for those in the most need, the welfare burden should be borne mainly by individuals and their families. Moreover, several Conservative MPs stressed that Labour's welfare policies were too generous and suggested instead significant targeted cuts in public spending.

TABLE 4. How do you think welfare services should be financed? (percentage of responses by party)

\begin{tabular}{lccccc}
\hline & Labour & Conservative & $\begin{array}{c}\text { Liberal } \\
\text { Democrat }\end{array}$ & $\begin{array}{c}\text { SNP/Plaid/ } \\
\text { Independent }\end{array}$ & $\begin{array}{c}\text { Total } \\
\%\end{array}$ \\
\hline $\begin{array}{l}\text { By the state through } \\
\text { general taxation and } \\
\text { national insurance }\end{array}$ & 63 & 0 & 90 & 100 & 51 \\
$\begin{array}{l}\text { Mainly by the state, but } \\
\text { individuals to take the } \\
\text { burden in certain sectors. }\end{array}$ & 37 & 75 & 10 & 0 & 42 \\
$\begin{array}{l}\text { Beyond a state funded } \\
\text { safety net -mainly by } \\
\text { individuals and their } \\
\text { families }\end{array}$ & 0 & 25 & 0 & 0 & 7 \\
\hline Number & 32 & 20 & 10 & 5 & 67 \\
\hline
\end{tabular}

However, while these results suggest marked divisions between the parties on the most appropriate means of paying for welfare, MPs' responses to the more vexed question of 'tax and spend' reveal a greater degree of consensus (Table 5). Only 29 per cent of MPs questioned favoured an increase in taxation to pay for increased services, compared to 71 per cent who stated clearly that they would not be in favour of such an increase. However, the bulk of those opposed to tax funded increases in provision were Conservative MPs, none of whom supported this; while Labour and Liberal Democrat MPs were fairly evenly divided, although in both cases the majority were opposed to tax increases. Perhaps predictably, in explaining their attitudes towards tax funded increases in provision, Labour MPs frequently pointed to the scars of eighteen years of opposition, and in particular the memory of the 1992 General Election. Interestingly, despite being the only party in recent years to have advocated increasing taxes to pay for public services, Liberal Democrat MPs were only slightly more supportive of this than Labour MPs. Several MPs from the Labour and Liberal Democrat parties pointed to the effect on incomes of Gordon Brown's 2002 budget in which national insurance contributions were increased, the redistributive effects of which were widely publicised shortly before the 2005 General Election (Brewer et al., 2005). While generally applauded by Labour and Liberal Democrat MPs, it was felt by many that this was enough, and that any further demands on the pay packets of the public would be unpopular, and electorally damaging.

TABLE 5. Would you be in favour of an increase in general taxation to pay for increased welfare provision? (percentage of responses by party).

\begin{tabular}{cccccc}
\hline & Lab & Cons & LD & $\begin{array}{c}\text { SNP/Plaid/ } \\
\text { Independent }\end{array}$ & $\begin{array}{c}\text { Total } \\
\text { \% }\end{array}$ \\
\hline Yes & 41 & 0 & 44 & 75 & 29
\end{tabular}




\begin{tabular}{lccccc} 
No & 59 & 100 & 56 & 25 & 71 \\
\hline Number & 22 & 20 & 9 & 4 & 40 \\
\hline
\end{tabular}

Indeed, on the question of paying for welfare, the main lines of consensus among MPs lie not so much in whether state funded provision is appropriate, or whether tax funded increases in provision are desirable, but whether such tax increases are acceptable to the electorate. There was widespread agreement among MPs from all parties, irrespective of their personal attitudes towards tax and spending, that restraints on taxes and public spending are essential for electoral success. Indeed, when asked to outline the main challenges facing the welfare state today, cost set against the public desire for lower taxes was the second most popular choice among both Labour and Conservative MPs, and was mentioned by more Liberal Democrat MPs than any other factor. Significantly, however, 'too much state provision' which was the most popular choice among Conservative MPs was not mentioned as being a significant challenge by MPs from any of the other parties.

\section{MPs' attitudes towards consensus}

Finally, it is instructive to consider the extent to which MPs themselves believe there to be some degree of consensus in approaches to welfare. MPs' responses to this question revealed a highly ambivalent attitude towards consensus (Table 6). Only 14 per cent of MPs were unequivocal in affirming the emergence of a political consensus, while a further 41 per cent believed there was some degree of consensus. However, a large proportion ( 45 per cent), believed there to be no consensus at all. A closer examination of MPs' responses reveals an even greater degree of ambivalence. Whilst the majority (55 per cent) believed there to be at least some degree of consensus, their responses were generally more varied and ambiguous than those who rejected the idea of consensus. MPs who disputed the emergence of a consensus were particularly forthright, reverting to entrenched party positions and on occasion expressing indignation at the suggestion. This was particularly the case with Labour and Conservative MPs. Liberal Democrat MPs as a whole were more sceptical about the idea of consensus, with none positively asserting the existence of consensus, and a common response among Liberal Democrats was, 'if there is a consensus we are not part of it'.

TABLE 6. Do you believe there is a political consensus around general approaches to welfare? (percentage of responses by party).

\begin{tabular}{|c|c|c|c|c|c|}
\hline & Labour & Conservative & $\begin{array}{c}\text { Liberal } \\
\text { Democrat }\end{array}$ & $\begin{array}{l}\text { SNP/Plaid/ } \\
\text { Independent }\end{array}$ & $\begin{array}{c}\text { Total } \\
\%\end{array}$ \\
\hline Yes & 13 & 11 & 0 & 40 & 14 \\
\hline $\begin{array}{l}\text { Some consensus on } \\
\text { objectives/ } \\
\text { language but not on } \\
\text { methods }\end{array}$ & 35 & 56 & 60 & 20 & 41 \\
\hline No & 52 & 33 & 40 & 40 & 45 \\
\hline Number & 31 & 18 & 10 & 5 & 64 \\
\hline
\end{tabular}

There was also a certain amount of scepticism as to whether the appearance of agreement on some aspects of welfare marked a genuine movement towards 
consensus. Several MPs pointed to similarities in the language used about welfare, but doubted whether this represented a genuine shift in attitudes. There was a certain degree of scepticism about Labour's commitment to welfare reform. Several Conservative MPs referred to the government's reluctance to allow Frank Field to 'think the unthinkable' on welfare reform. The use of the language of reform was, according to one Conservative MP, a smokescreen behind which Gordon Brown was expanding the 'welfare basket', or as one Liberal Democrat put it, 'madly redistributing'. Indeed, several MPs from all parties expressed the belief that there would be a return to more universal provision should Gordon Brown become Prime Minister. Similarly, Labour MPs expressed doubts that Conservative commitments to combat poverty and unemployment would be sustained in office, and pointed to Conservative plans to dismantle the New Deal as evidence of this.

It was also striking that few MPs readily viewed the pursuit of consensus as something to aspire to. Only five MPs, three Labour and two Conservatives, expressed the belief that the parties should be actively seeking a new consensus on welfare, and only one of these, a Conservative, expressed confidence that this could be achieved, stating rather optimistically, 'we're all completely at one with Frank Field now', a view markedly not shared on the Labour benches. Many Labour MPs were decidedly critical of the movement towards consensus, reluctantly conceding that Labour's use of the private sector in welfare provision marked the emergence of a new consensus but not one with which they were happy, or indeed wished to be part of. One Labour MP who was leaving Parliament at the 2005 General Election, was harshly critical of competition for the 'soggy centre' which had stultified debate and undermined the welfare state. Indeed, few MPs from any party appeared to conceive of consensus as being arrived at by debate and compromise leading to movement on the part of all the parties towards some centre ground. Where MPs did recognise some consensus it was widely felt that this had been achieved by one party moving towards the position of the other. This was particularly evident among those Labour MPs who opposed the private sector, and selective provision, and also among Conservative MPs who were more inclined to believe that the balance of opinion was moving in their direction.

Nevertheless, some MPs did believe there had been a positive movement on the part of the main parties towards a new consensus on welfare and their responses suggest that this movement had been broad based and not confined to the party leadership. MPs referred to 'realignment', 'movement towards an imaginary middle from both sides', 'a coming together of Tory and New Labour thinking', and 'a realisation that we need to do things differently'. However, where MPs did identify a consensus it was largely related to objectives, and there remained fundamental differences of opinion over how to achieve these objectives. There was, for example, notable consensus on the need to combat poverty particularly among children and pensioners, but disagreements over the means of achieving this, particularly over pensions means testing and the operation of tax credits. Similarly, reflecting similarities of position as outlined earlier, MPs identified a consensus on the importance of propelling people into work, based upon the idea, as one Labour MP put it, 'that work is normal, being on benefit is not'. However, there remained areas of disagreement over the extent to which Labour's policies would achieve this. Many Conservative MPs, and a significant number of Liberal Democrat MPs, still felt the benefits system was a serious disincentive to work. Even where there was consensus 
over means, such as the increased use of mixed provision, there remained fundamental differences of opinion over how this provision should be managed. Thus, for example, while Conservative MPs supported the government's attempts to involve the charitable sector in welfare provision, they were critical of the fact that from their perspective, charities were not being allowed to drive need but were instead being coopted to the government's agenda.

\section{A new consensus?}

In considering whether there has been any development of a new consensus on welfare it is important to recognise that whatever the situation in the House of Commons it is not clear how far this would extend beyond the three main parties in Parliament. Several MPs pointed to what they perceived as differences in attitudes between the Parliamentary and constituency parties, with the former generally being viewed by MPs as closer to the centre and the latter tending towards less consensual approaches to welfare provision. It is also interesting to observe that the shifts in attitudes within the three main parties are not reflected in the views of (the admittedly small number of) MPs from Plaid Cymru and the SNP, who generally supported a high level of universal state provision. This raises questions about the implications of such differences for the provision of welfare in Scotland and Wales, and these are clearly reinforced by the existence of the National Assembly for Wales and the Scottish Parliament, both of which have already deviated from some of the social policy positions adopted at Westminster in the relatively short periods of their existence. In addition, it is not clear the extent to which the shifts in politicians' attitudes to the welfare state are reflected in public opinion (Curtice and Fisher, 2003; Taylor-Gooby, 2004), a marked feature of the post-war consensus on welfare.

Nevertheless the situation within Parliament remains important for the development of social policy, as evidenced by the experiences of both Conservative and Labour governments since 1979, and there has clearly been some significant movement towards a middle ground in MPs' attitudes to welfare and this in turn lends some support to the idea that there is an emerging consensus. This is particularly evident in any comparison of the attitudes of MPs today with those of the 1980s, a period when there was little or no consensus on approaches to welfare. However, if there is some return to consensus on welfare it is a new consensus. The post-war consensus involved considerable cross party agreement on means: a commitment to the mixed economy; the maintenance of full employment through Keynesian economic management; and a high level of state welfare provision. There were however, fundamental differences of opinion over objectives, with the Labour party committed to the redistribution of wealth and the Conservatives seeking a degree of intervention sufficient only to be compatible with market efficiency and personal initiative (Lowe, 2005). The current survey reveals a significantly different situation within Parliament. Labour MPs, aware of the escalating costs of welfare provision, have moved away from ideas centred on universal provision towards a more selective targeted approach to welfare. At the same time some Conservative MPs, aware of the damaging social costs of poverty, have shifted away from a strictly minimal approach to welfare towards a more collectivist position, whilst the appetite for tax cuts is significantly less than in the 1980s. There is therefore some convergence of attitudes on a middle ground defined by financial restraint and the mixed provision of welfare services, designed to help those in most need, while enabling others to help 
themselves. There is now arguably a broad consensus on ends, the elimination of poverty particularly among pensioners and children, the movement of people off welfare and into work, and the creation of a competitive economy by restraining spending and the burden of taxation. There are some areas of consensus on the means of achieving this, most notably through a commitment to mixed provision. However, there remain fundamental differences relating to the delivery of these objectives, with areas of disagreement over issues such as means testing, the minimum wage and tax credits.

Whilst this survey of MPs' attitudes does therefore provide some evidence to support the work of Taylor-Gooby and others who have suggested the emergence of a new consensus on welfare, it is not conclusive. There has clearly been some movement of MPs towards a centre ground on welfare, but it is not clear how firm this ground is. There is still strong support among backbench MPs for approaches to welfare provision which reflect the poles of traditional Labour and Conservative values of social justice and minimal state support. A significant proportion of Labour MPs (22 per cent) continue to believe that the role of the state should be to redistribute wealth, while an even larger proportion of Conservative MPs (33 per cent), believe that the state should provide nothing more than a minimal safety-net for those in the most need (Table 2). In the case of Labour MPs, support for redistribution has changed little since the 1980s when 29 per cent of Labour MPs adopted this position (Bochel, 1992). Indeed, many Labour MPs who took part in this survey expressed grave misgivings about aspects of Labour's programme of welfare reform, most notably the involvement of the private sector, and expressed strong opposition to the movement towards a new consensus based on selective and mixed provision. This is reflected in marked divisions within the Labour party in relation to the financing and provision of welfare (Tables 3, 4 and 5). Significantly, these MPs were not primarily well-known Labour rebels, but rather were MPs whose voting records are solid and which compare favourably with that of the Prime Minister. Similarly, the research suggested the existence of a group of Conservative MPs interested in developing considerable state support for individuals and communities in need. However, these Conservative MPs were themselves unable to estimate the depth of support for this position within even the Parliamentary party, although the leadership election later in 2005 did help to highlight the existence of such views. In contrast, there remained strong support among Conservative MPs for a limited approach to welfare. There were powerful arguments about the disincentive nature of state provision and, despite the Howard Flight debacle immediately prior to the 2005 general election, several who called for increased charging or fundamental cuts in services. It is likely therefore, that any 'new consensus' in Parliament will remain contestable not only between, but also within parties. 


\section{References}

Addison, P. (1975), The Road to 1945, London: Cape.

Addison, P. (1993), 'Consensus Revisited', Twentieth Century British History, 4, 1: 91-4.

Beer, S. (1965), Modern British Politics, London: Faber and Faber.

Bochel, H. (1992), Parliament and Welfare Policy, Aldershot: Dartmouth.

Bochel, H. and Defty, A. (2005), 'Public and Parliamentary Attitudes to Welfare', paper presented at the Political Studies Association Annual Conference, 2005 (http://www.psa.ac.uk/2005/pps/Bochel.pdf).

Brewer, M., Goodman, A., Shaw, J. and Shephard, A. (2005), Poverty and Inequality in Britain: 2005, London: Institute for Fiscal Studies.

Cowley, P. (2005), The Rebels: How Blair mislaid his majority, London: Politico's

Curtice, J. and Fisher, S. (2003), 'The Power to Persuade? A Tale of Two Prime Ministers', in A. Park, J. Curtice, K. Thomson, C. Bromley and M. Phillips (eds), British Social Attitudes: the 20th Report, Continuity and Change Over Two Decades, London: Sage.

Hickson, K. (2004), 'The Postwar Consensus Revisited', Political Quarterly, 75: 2, 142-154.

Jones, H. and Kandiah, M. (1996), The Myth of Consensus: New Views on British History, 1945-64, London: Macmillan.

Kavanagh, D. (1985), 'Whatever Happened to Consensus Politics?', Political Studies, 33: 4, 529-46.

Kavanagh, D. (1990), Thatcherism and British Politics: The End of Consensus?, Oxford: Oxford University Press.

Kavanagh, D. and Morris, P. (1994), Consensus Politics from Attlee to Major, Oxford: Blackwell.

Lowe, R. (2005), The Welfare State in Britain since 1945, Basingstoke: Palgrave.

Lilleker, D.G. (2003), 'Interviewing the Political Elite: Navigating a Potential Minefield', Politics, 23: 3, 207-214.

Marquand, D. (1988), The Unprincipled Society, London: Fontana.

Miliband, R. (1983), Class Power and State Power, London: Verso.

Pierson, C. (1991), Beyond the Welfare State?, Cambridge: Polity. 
Pimlott, B. (1988), 'The Myth of Consensus', in L. M. Smith (ed.), The Making of Britain: Echoes of Greatness, Basingstoke: Macmillan.

Seldon, A (1994), 'Consensus: A Debate Too Long?', Parliamentary Affairs, 47: 4, 501-14.

Taylor-Gooby, P. (1991), 'Attachment to the Welfare State', in R. Jowell, L. Brook, B. Taylor and G. Prior (eds), British Social Attitudes: the $8^{\text {th }}$ Report, Aldershot: Dartmouth.

Taylor-Gooby, P. (ed.) (2001), Welfare States under Pressure, London: Sage.

Taylor-Gooby, P. (2001), 'Welfare Reform in the UK: the Construction of a Liberal Consensus', in P. Taylor-Gooby (ed.), Welfare States under Pressure, London: Sage.

Taylor-Gooby, P. (2004), 'The Work-Centred Welfare State', in A. Park, J. Curtice, K. Thomson, C. Bromley and M. Phillips (eds), British Social Attitudes: the $21^{\text {st }}$ Report, London: Sage.

Taylor-Gooby, P. and Bochel, H. (1988), 'Public Opinion, Party Policy and MPs' Attitudes to Welfare', Political Quarterly, 59: 2, 251-8.

Thane, P. (1982), The Foundations of the Welfare State, London: Longman.

Timmins, N. (1995), The Five Giants: a biography of the welfare state, London: Harper Collins.

Williams, M. (2000), Crisis and Consensus in British Politics: From Bagehot to Blair, London: Macmillan.

Wilton, I. (1990), 'Postwar Consensus: Some Issues Re-examined', Contemporary Record, 3:4, 27-8. 